\title{
Upaya Pembinaan Karakter Peserta Didik, Menghadapi Dampak Globalisasi
}

\author{
Muhasim \\ STIT Palapa Nusantara Lombok NTB \\ mhmsaidah@gamail.com
}

\begin{abstract}
Everyone wants good character, noble morality, to attain happiness for himself, in life, religion, society, and nation. Therefore, various efforts were made, including the character coaching efforts for the students, as the next generation of religious and national struggles. The ideal character is the the rightmost character who always obey the religious values he believes, the norms that are the basis of community life and nationality. The result of the ideal character, growing compassion, respectful respect, security and tranquility, motivation to realize the life of a happy world and the hereafter. The problem is still a group of people who can not realize the ideal character, causing stress, resulting in the behavior of corruption, collusion, nepotism, pungli, liquor party, drugs, sadistic, murder, student Tauran, Radicalism, terrorism. This study discusses the students 'coaching efforts to face the influence of globalization, so that it can run the character Idel on oneself, and not be guided by the suspected phenomenon of alleged character in some groups, Whether it be, rulers, politicians, civic organizations, students and other youth groups. The method used is a qualitative, descriptive method, using observation sources, documents, scientific books, Interent. The results of the study became a reference to realizing the nation's expectations, the creation of students with noble, spiritual and cultural character, in the series of societies and nations that are just and prosperous.
\end{abstract}

Keywords: coaching, characters, learners, Globalissi

\begin{abstract}
Abstrak: Setiap orang menghendaki karakter yang baik, akhlak yang mulia, untuk mencapai kebahagian hidup bagi dirinya, dalam menempuh kehidupan, beragama, bermasyarakat dan berbangsa. Karena itu berbagai upaya dilakukan, termasuk upaya pembinaan karakter bagi peserta didik, sebagai generasi penerus perjuangan agama dan bangsa. Karakter yang ideal adalah karaker yang selalu taat menjalankan nilainilai agama yang diyakininya, norma -norma yang menjadi dasar hidup bermasyarakat dan berbangsa. Akibat dari karakter yang ideal tersebut, tumbuh rasa kasih sayang, hormat menghormati, keamanan serta ketentraman, motivasi untuk mewujudkan kehidupan yang bahagia dunia dan akhirat. Masalahnya masih ada sekelompok orang yang tidak bisa mewujudkan karakter ideal tersebut, sehingga menyebabkan stress, mengakibatkan terjadinya perilaku korupsi, kolusi, nepotisme, pungli, pesta miras, narkoba, begal sadis, pembunuhan, tauran pelajar, radikalisme, terorisme dsbnya. Penelitian ini membahas upaya pembinaan karakter peserta didik menghadapi pengaruh globalisasi, sehingga dapat menjalankan karakter idel pada diri sendiri, dan tidak terbius dengan fenomena rusaknya karakter yang diduga terjadi pada beberapa
\end{abstract}

Islamika : Jurnal Keislaman dan Ilmu Pendidikan

Volume 2, Nomor 1, Januari 2020; 97-119

https:// ejournal.stitpn.ac.id/index.php/islamika 
kelompok, apakah itu, penguasa, politisi, organisasi kemasyarakatan, pelajar dan kelompok remaja lainnya. Metode yang dipakai yaitu, metode deskriptif kualitatif, menggunakan sumber pengamatan, dokumen, buku-buku ilmiah, Interent. Hasil penelitian menjadi acuan mewujudkan harapan bangsa, terciptanya peserta didik berkarakter mulia, spiritual maupun kultural, dalam rangkaian terciptanya masyarakat dan bangsa yang adil dan makmur.

Kata Kunci : Pembinaan, Karakter, Peserta Didik, Globalissi.

\section{PENDAHULUAN.}

Semua manusia yang sudah mampu berpikir atau dewasa menghendaki karakter yang baik artinya akhlak yang mulia, ucapan dan perelaku sesuai dengan nilai-nilai agama yang diyakininya. Berkata santun, berperilaku yang terpuji, sesuai dengan perintah Allah SWT dan Rasulnya Muhammad Saw, dan nilai-nilai moral Pancasila sebagai Ideologi bangsa. Menciptakan harapan itu, secara kholistik setiap orang dan semua institusi pemerintah maupun swasta menjalankan pembinaan karakter yang mulia itu. Pemerintah dan swasta mendirikan Lembaga Pendidikan, Guru melalui perannya sebagai guru, pemimpin melalui perannya sebagai pemimpin, orang tua menjalankan kewajibannya sebagai orang tua. Artinya bahwa pembinaan karakter terpuji itu, merupakan peran semua pihak, setiap komponen ini secara kholistik sama-sama menghendaki tercipatanya akarakter yang baik atau akhlak mulia.

Kenyataannya pembinaan karakter itu tidak semudah membalik tangan, fenomena yang berkembang justru kerusakan karakter, terjadi tauran pelajar, pesta miras, narkoba, menyebarnya paham radikalisme, terorisme, mengaku nabi / palsu, di Kalimantan Selatan, pembunuhan, pencurian, begal sadis. Begal sadis, masih usia sekolah di Makasar Sulsel, pencurian dengan memperalat anak sendiri di Surabaya, Sindikat uang palsu, Begal sepeda motor,sadis, tewas di tembak polisi pencuri sepeda motor di Bandar Lampung, Sidikat uang palsu di Jember, diringkus Polisi, pembunuhan yang terjadi yang korbanya mulai anak-anak, bosnya, istrinya, ibunya, bapaknya, sudah tidak memiliki rasa perikemanuasiaan. Lain lagi kelompok yang mengklaskan dirinya kelompok modern, mulai dari cara berpakaian yang sudah tidak sesuai nilai agama dan budaya setempat, penyebaran gambar forno lewat media sosial, belum lagi korupsi terus terjdi, kolusi, nepotisme dan pungli. Tauran pelajar terjadi di banyak wilayah mulai Jakarta dan wilayah lainnya, sudah sering terjadi, Bandar dan 
pengedar dan pengguna narkoba dan sejenisnya, fenomena sering terjadi, mulai dari yang kaya sampai sopir bahkan pelajar, pesta miras di Bali berujung pembunuhan, atau wilayah lain, tauran pelajar baru saja terjadi di Tangerang Banten, mengakibatkan satu orang meninggal dunia. Dan banyak lainnya lagi, tidak bisa disebut secara lengkap, silahkan dicermati diwilayah tempat tinggal masing-masing.

Minuman keras yang memabukkan sudah sangat mudah kita saksikan, tidak lagi ditempat sepi dan terpencil, tetapi didepan toko-toko, para petugas parkir minumannya adalah miras, pokoknya begitu ada kumpulan sekelompok pemuda dipinggir jalan, depan toko, jembatan, trotoar-trotoar, dapat diasumsi mereka melakukan pesta miras, justru pelakunya masih usia peserta didik. Penggunaan obatobat terlarang, narkoba, dan sejenisnya dalam riset yang diadakan oleh Badan Narkoba Nasional dan Pusat penelitian Universitas Indonesia terungkap bahwa biaya ekonomi dan soaial penyalahgunaan narkoba di Indonesia ( 2004 ) mencapai Rp.23,6 triliun.

Penyebaran paham radikalisme dan terorisme, sudah menggunakan media online, sehingga dapat menyebar dengan mudah melalui media sosial, yang sebagain terbesar usia peserta didik. Pertukaran nilai-nilai budaya yang tidak selamanya sesuai dengan nilai-nilai budaya daerah setempat, dapat mempengaruhi perubahan perilaku para remaja dan generasi muda, tergolong peserta didik. Belum lagi perubahan karakter masyarakat, akibat politik uang serta janji-janji politik para pencari kekuasaan. Fenomena negatif yang terjadi dalam kehidupan bermasyarakat tersebut diyakini karena ketiadaan karakter, dilakukan karena ketidak jujuran dan sering-sering berujung dusta. Allah Ta'ala befirman, “ Dan pada hari kiamat kamu akan melihat orang-orang yang berbuat dusta terhadap Allah, mukanya menjadi hitam ( Az - Zumar:60).

Eri Sudewo dalam buku Best Practice Charakter, yang menyebutkan karena kenihilan karakter itu, jika hal itu terus diabaikan, bangsa ini akan masuk ke tepi jurang yang dinamakan negara gagal. ${ }^{1}$ Selain itu pertukaran informasi yang memberitakan peristiwa-peristiwa yang terjadi diluar sana baik positif maupun negatif dapat menyebar dengan sangat cepat dan luas, dapat berpengaruh terhadap

1. Anas Salamudin, Drs.M.Pd dan Irwanto Alkarienciehie, Pendidikan Karakter, Penerbit CV. Pustaka Setia, Bandung, Tahun 2013: 30. 
karakter masyarakat termasuk peserta didik. Pengaruh fenomena tersebut, bukan saja mengganggu, tetapi dapat merusak karakter masyarakat, oleh karena itu harus ada upaya pembinaan karakter peserta didik, sebagai kader penerus perjuangan bangsa Indonesia.

Pengaruh positif tehnologi informasi yang sudah sangat maju, memberikan manfaat serta dukungan terhadap perkembangan ilmu pengetahuan. Sebaliknya semakin besar pengaruh negatif dari globalisasi, semakin rumit tantangan yang dihadapi dalam upaya pembinaan karakter peserta didik, sehingga untuk menghadapi tantangan tersebut diperlukan upaya-upaya yang dapat mengarahkan, mengatasi serta mengambil manfaat positif dari globalisasi. Fenomena perilaku buruk yang berkembang sebagaimana diuraikan di atas, sebagai simbul hilangnya karakter. Oleh karena itu Penelitian ini membahas bagaimana Upaya Pembinaan Karakter Peserta Didik, menghadapi Dampak Globalisasi.

\section{KAJIAN PUSTAKA}

\section{Pembinaan}

Pembinaan adalah ujud dari sebuah upaya untuk menjadikan sesuatu lebih baik. Berupaya yaitu berusaha (berikhtiar), berdaya upaya. Mengupayakan yaitu mengikhtiarkan, melakukan sesuatu utuk mencari akal, mengambil tindakan. ${ }^{2}$ Pembinaan dalam Kamus Besar Bahasa Indonesia, dinyatakan bahwa membina sebagai upaya mengusahakan supaya lebih baik, pembinaan adalah proses, pembuatan, cara membina agar berhasil guna untuk memperoleh hasil yang lebih baik. ${ }^{3}$

Proses adalah runtutan perubahan ( peristiwa) dalam perkembangan sesuatu. ${ }^{4}$ Perkembangan sesuatu dalam pengertian ini, ditekankan pada perubahan karakter sebagai hasil pembinaan. Dalam pengertian pembinaan karakter di era globalisasi lebih logis pendekatan pemahaman yang dipakai adalah proses

2 W.J.S. Poerwadarminta, Kamus Umum Bahasa Indonesia, Penerbit Balai Pustaka, Jakarta, Tahun 1982: 137.

3 . Departemen Pendidikan dan Kebudayaan, Kamus Besar Bahasa Indonesia, Penerbit Balai Pustaka, Jakarta, Tahun $1990: 389$.

${ }^{4}$. Ibid, Departemen Pendidikan dan Kebudayaan, Kamus Besar Bahasa Indonesia, Penerbit Balai Pustaka, Jakarta, Tahun $1990: 703$. 
perubahan sosial yang terus berubah, sehingga fase pembinaan perubahan harus bersesuaian dengan perkembangan sosial sebagai ujud globalisasi. Pembuatan, memiliki pengertian perilaku atau tindakan pembinaan yang harus dilakukan agar berhasil guna untuk memperoleh hasil yang lebih baik.

Pembinaan karakter ( ahklak mulia) membutuhkan proses dan cara strategi yang cocok dengan kasus karakter yang perlu diperbaiki karena diasumsi sudah menyimpang dari nilai-nilai keagamaan maupun kebangsaan. Cara membina diusahakan sesuai dengan kasusnya atau hasil diagnosenya. Obat penyakit panas tentu berbeda dengan obat sakit pencernaan dstnya. Karakter seseorang berbeda-beda, tentu akan menggambarkan perilaku yang berbeda. Kerusakan karakter juga akan berbeda tergantung variabel pengaitnya, yang justru sangat beragam, koruptor beda prosesnya dengan perampokan, walaupun maknanya sama-sama merampok uang milik rakyat, yang doyan pesta miras, berbeda dengan narkoba, walupun sama-sama memabokkan.

Pembinaan, pengobatan banyak cara untuk mengembalikan kerusakan karakter pada seseorang, dalam upaya mengembalikan nilai-nilia yang benar untuk dilakukan dengan benar, tidak semudah kita mengatakan. Seseorang berperilaku melanggar nilai, untuk mewujudkan suatu harapan tentu beranggapan apa yang dilakukan itu baik, aji mumpung berkuasa, memiliki peluang dan berangapan tidak ada seorangpun mengetahui, Ia lupa bahwa rekaman CCTV Allah itu, tidak pernah mengenal listrik mati.

Berbicara pembinaan idealnya yang akan membina adalah pemimpin, tetapi kalau pemimpinnya sudah tidak lagi pantas ditiru, diteladani, siapa lagi yang akan melakukan pembinaan. Kita kembali kepada makna bahwa manusia itu halifah di bumi, bahwa dirinya adalah pemimpin, minimal memimpin dirinya sendiri, maka setiap orang akan mempertanggung jawabkan apa yang sudah dilakukan dirinya dan terhadap orang lain. Artinya bahwa setiap orang harus membina diri terhadap sikap dan perilakunya. Selain institusi sudah menyediakan balai-balai pembinaan, lembaga-lembaga kursus dan pelatihan, para konsultan sumber daya mansusia, khusunya Lembaga Pemasyarakatan, sebagai salah satu cara penjeraan dengan memberikan hukuman yang setimpal dari penyimpangan 
yang dilakukannya, sementara menunggu pertanggungjawaban kepada sang pencipta.

2. Karakter

Karakter dalam Kamus Besar Bahasa Indonesia disebutkan sebagai asifat-sifat kejiwaan, akhlak atau budi pekerti yang memberdakan seseorang dengan yang lain, tabiat, watak. ${ }^{5}$.

Karakter ialah sifat-sifat kejiwaaan, akhlak atau budi pekerti yang membedakan seseorang dari orang yang lain, tabiat atau watak ( Departemen Pendidikan Nasional, 1977:444) $)^{6}$.

Character artinya tabiat, watak, sifat, peran, huruf,jenis. ${ }^{7}$ Bahasa Yunani Charasein artinya "mengukir corak yang tetap dan tidak terhapuskan, sehingga karakter atau watak" merupakan perpaduan dari segala tabiat manusia yang bersifat tetap sehingga menjadi tanda khusus untuk membedakan orang yang satu dengan yang lain" ( Dewantara $: 87)^{8}$.

Samuel Smiles (2003;vii) dalam Haedar Nasir ( 2013:11) bahwa karakter adalah suatu kehormatan dalam diri seseorang, sebagai harta paling mulia. Karakter merupakan niat baik dan kehormatan umum seseorang, sebagai investasi berharga, meskipun mereka mungkin tidak menjadi secara materi duniawi ${ }^{9}$.

Sudewo ( 2011:15-16 ) dalam Haidar Nasir ( 2013:13), menyebut ada karakter pokok dan karakter pilihan. Karakter pokok meliputi karakter dasar, karakter unggul dan karakter pemimpin. ${ }^{10}$ Dikutif dari penjelasan Sudewo, Karakter dasar meliputi sifat tidak egois, jujur dan disiplin. Karakter unggul terdiri dari sifat ikhlas, sabar, bersyukur, bertanggungjawab, berkorban, memperbaiki diri dan sungguh-sungguh. Karakter pemimpin meliputi sifat : adil, arif, bijaksana, kesatria, tawadhu, sederhana, visioner, solutit, komunikatif, dan inspiratif. Sedangkan Karakter pilihan menggambarkan perilaku baik yang berkembang sesuai dengan profesi pekerjaan masing-masing, misalnya karakter guru berbeda dengan karakter militer.

5. Ibid, KBBI : 389.

6. Haedar Nasir Dr, Pendidikan Karakter Berbasis Agama dan Budaya, Penerbit : Multi Presindo, Yogyakarta, Tahun 2013: 10 .

7. Wojowasito dan Tito W,Kamus Bahasa Inggris, Penerbit HASTA, Bandung, tahun 1980 :23.

8. Lokcit, Haedar Nasir : 10.

9. Ibidt, Haedar Nasir 2013: 11 .

10. Ibid, Haedar Nasir 2013: 13. 
UU No 20 Tahun 2003. tentang Sistem Pendikan Nasional, secara eksplisit dapat diambil maknanya, bahwa pembinaan karakter peserta didik yaitu upaya pengembangan potensi individu masing-masing, baik secara spiritual keagamaan, maupun secara profesional sehingga memiliki skill, kepribadian yang mulia dalam upaya membekali diri, untuk mengabdi kepada agama, masyarakat dan bangsa.

Pendapat para ahli, di atas dapat disimpulkan bahwa karakter ideal adalah sifat seseorang individu yang baik, yang ditunjukkan dengan perilaku berdasarkan nilai-nilai yang diyakini kebenarannya. Agama Islam menggunakan istilah akhlak mulia, secara kontemporer menyebutnya moral, sikap serta perilaku yang sopan, ucapan yang santun. Ia tampil sebagai orang yang bermoral yang cerdas menciptakan kehormatan dan martabatnya, karena setiap perilaku, perbuatannya, didasari pertimbangan nilai-nilai akhlak mulia, sehingga memiliki investasi karakter mulia, kehormatan, kharisma baik, yang dapat diterima secara umum, meskipun tidak tampak keuntungan materi secara duniawi.

\section{Peserta Didik}

Peserta didik menurut UU No: 20 Tahin 2003 tentang Sistem Pendidikan Nasional adalah anggota masyarakat yang berusaha mengembangkan potensi diri melalui proses pembelajaran yang tersedia pada jalur, jenjang dan jenis pendidikan tertentu. ${ }^{11}$.

Oemar Hamalik, Peserta didik merupakan suatu komponen masukan dalam system pendidikan, yang selanjutnya diproses dalam proses pendidikan, sehingga menjadi manusia yang berkualitas sesuai dengan tujuan pendidikan. ${ }^{12}$.

Abu Ahmadi, berpendapat bahwa peserta didik adalah sosok manusia sebagai individu/pribadi ( manusia seutuhnya). Individu diartikan orang seorang tidak tergantung dari orang lain, dalam arti benar-benar seorang pribadi yang

11. Eka Prihatin, Manajemen Peserta Didik, Penerbit,Alfabeta Bandung, Tahun 2014 : 3.

12. Sukarti Nasihin dan Sururi, Manajemen Peserta didik, Penerbit Alfabeta, Bandung, Tahun 2012 : 203. 
menentukan diri sendiri dan tidak dipaksa dari luar, mempunyai sifat-sifat dan keinginan sendiri. ${ }^{13}$

Mendapatkan pendidikan merupakan hak mutlak peserta didik, sebagaimana dikemukakan Hamid Darmadi, bahwa Pendidikan merupakan hak mutlak yang harus dipenuhi dalam upaya meningkatkan taraf hidup bangsa agar tidak sampai menjadi bangsa terbelakang dan tertinggal dengan bangsa lain. ${ }^{14}$

Dari pendapat para pakar tersebut di atas, disimpulkan bahwa Peserta didik adalah Individu yang memiliki hak untuk mengembangkan motivasi meningkatkan kompetensi diri dengan mencari ilmu pengetahuan umum, pendidikan kejuruan, maupun pendidikan Vokasi/ keterampilan tertentu sesuai dengan minat dan kemampuan yang dimiliki. Motivasi tersebut didirong oleh adanya kehendak diri sendiri, untuk menghadapi dan mewujudkan cita-cita, harapan kehidupan yang lebih baik dan kesejahteraannya. Kehidupan yang lebih baik, adil, sejahtera, aman lahir dan bathin, dan akan berpengaruh kepada kehidupan yang lebih baik bagi masyarakat, dan bangsa.

\section{Globalisasi}

Globalisasi dari aspek informsi dan interaksi komunikasi, telah mejadi perantara pengenalan kehidupan masyarakat dan budaya berbagai etnis dan bangsa-bangsa di dunia, sehingga tercipta saling pengertian diantara berbagai bangsa. ${ }^{15}$

Uraian tersebut memberikan pemahaman bahwa saling pengertian serta pemahaman terhadap budaya masing-masing bisa saja terjadi perbedaan dan menjadi hak hidup masing-masing pihak. Dampak pertukaran budaya tersebut dari berbagai bentuk pemahaman masing-masing sumber daya manusia dari kedua

\footnotetext{
13. Tim Dosen Administrasi Pendidikan Universitas Penddikan Indonesia, Manajemen Pendidikan, Diterbitkan oleh Alfabeta, Bandung, tahun $2012: 205$.

14. Prof. DR. Hamid Darmadi,MPD.,MSC, Pengantar Pendidikan Era Globalisasi,

Penerbit,An1mage, Jakarta, tahun 2019: 2 .

15 .Muhammad Hisyam dan Cahyo Pamungkas ( Ed ),Indonesia globalisasi dan globalisasivillage, Penerbit, Yayasan Pustaka Obor Indonesia, Tahun 2016:6
} 
komunitas, dapat berdampak positif terhadap peningkatan pengetahuan, keterampilan dan kesejehteraan bersama.

Menurut Hisyam, di kalangan masyarakat peduli moral, dan tertib masyarakat, globalisasi dianggap menimbulkan kehidupan hedonis, dekadensi moral dan kekacauan dalam masyarakat. Masyarakat yang berkehidupan liberal bebas seperti dalam perilaku seks, mengkomunikasikan cara interaksi seksual keluar budaya mereka, melalui forno aksi, menular kemasyarakat dasar budayanya puritan, terhadap perilaku seks bebas. ${ }^{16}$

Perbedaan yang positif menimbulkan kemudahan manusia untuk peningkatan ilmu pengetahuan serta keterampilan, dibalik itu negatifnya seperti perbedaan pemahaman yang mungkin saja menimbulkan benturan pemahaman dan kekacauan. Menurut Hisyam diambil Contoh actual adalah visualisasi Nabi Muhammad oleh seniman Eropha yang di Ekspose dalam media cetak, media elektronik dan film, telah menimbulkan ketersinggungan masyarakat muslim di dunia. Agama Islam memang mengharamkan visualisasi Nabinya dalam bentuk apapun dan prinsip ini diyakini secara ijmak oleh Muslim diseluruh dunia. Sekali ini terjadi dan masyarakat muslim dan media di seluruh dunia menanggapinya dan kegaduhan global pun terjadi. Kemajuan teknologi akibat pesatnya arus globalisasi, merubah pola pengajaran pada dunia pendidikan. Pengajaran yang bersifat klasikal berubah menjadi pengajaran yang berbasis teknologi baru seperti internet dan computer. ${ }^{17}$

\section{PEMBAHASAN.}

\section{Upaya Pembinaan Karakter.}

Secara alamiah setiap orang lahir bersama karakternya, namun karakter ini bisa baik bisa menjadi buruk, bahkan karakter bisa hilang, ibarat Iman seseorang bisa bertambah, bisa berkurang dan bisa hilang. Jika ditelusuri fenomena yang terjadi apakah itu, korupsi, kolusi, nepotisme, pungli, pesta miras,

16. Ibit, Muhammad Hisyam dan Cahyo Pamungkas (Ed ),: 6.

17. Kalbin Salim Mira Puspa Sari, Jurnal Pengaruh Globalisasi Terhadap Dunia Pendidikan, Universitas Tehnologi Malaisia,Tahun 2015. 
pesta narkoba, begal sadis, pembunuhan sadis, perkelahian pelajar, karena hilangnya karakter, artinya tidak jauh beda dengan perilaku hewani. Manusia dengan hewan, yang membedakan adalah naluri, akal dan pekirannya, sehingga ia memiliki kehormatan, tahu nilai kebaikan serta mampu berbuat baik. Hakikat manusia itu adalah makluk beriman, diciptakan paling sempurna, menjadi khalifah dimuka bumi ini, mengatur kehidupan, bukan diatur kehidupan dan alam. Hal ini sesuai rumusan dari Kementerian Pendidikan Nasional, khusunya Direktorat Pendidikan Tinggi menjelaskan bahwa secara umum, arti karakter mendemontrasikan etika atau sitem nilai personal yang ideal ( baik dan penting) untuk eksistensi diri dan berhubungan dengan orang lain. ${ }^{18}$

Karakter manusia jika diurai pendapat pakar di atas, menurut penulis dapat dikelompokkan menjadi dua, yaitu karakter baik dan karakter baik, menurut istilah agama, akhlak mulia yaitu sikap baik dan tercela, perilaku baik dan perilaku keji. Dalam bahasa umum ada yang menyebutnya etika, merujuk kepada nilai ia yakini, yang memberikan simbul perilaku seseorang yang baik, berdasarkan standar nilai dan penilain masyarakat. Seseorang pasti memiliki standar nilai apakah itu agama, kepercayaan yang diyakini maupun adat istiadat, sebagai instrument menilai karakter seseorang, baik dalam penilain masyarakat atau atasan bila kita sebagai karyawan. Perilaku atau tindakan yang dilakukan seseorng mentaati standar nilai, yang dilakukan seseorang, tentu penilaian masyarakat beragam, tergantung pandangan masing-masing.

Perilaku masyarakat akan mengalami perubahan secara evolusi atau revolusi, sebagai pengaruh lingkungan sosial lokal atau global, bisa negatif atau positif. Perubahan itu sudah menjadi sebuah kewajaran, ibarat perubahan siang dan malam, berputar seirama dengan perjalanan hidup manusia, berhadapan dengan perubahan sosial yang mendunia. Perubahan mendunia menimbulkan perbedaan asumsi dalam mengklasifikasikan penyebab masalah kenihilan karakter dan cara pembinaanya.

\footnotetext{
18 . Anas Salahudin,Drs, M.Pd dan Irwanto Alkrienciehie, S.Ag, Pendidikan Karakter, Penerbit, CV Pustaka Setia, Bandung, Tahun 2012: 42.
} 
Kemelut Indonesia yang semakin carut marut ini salah satu penyebabnya adalah kenihilan karakter. Jika ini terus diabaikan, maka menurut Sudewo, bangsa ini menjadi limbung, akan masuk ke tepi jurang yang dinamakan negara gagal. ${ }^{19}$ Menurut Arif Punto Utomo, dalam Republika ( 24 Juli 2011), bangsa ini lemah dalam karakter. Karakter bangsa adalah sekumpulan karakter individu di sebuah negara. Lebih lanjut dikatakan bangsa melalui pimpinannya dapat membentuk karakter individu yang mumpuni, akan membawa bangsa dalam mewujudkan kesejahteraan sebagai cita-cita paling ideal bangsa ini. ${ }^{20}$

Peristiwa negatif yang sangat komflek, hubungan sosial carut marut, dari berbagai asumsi di atas disebabkan kenihilan karakter, dengan berbagai variabel pengait. Hal ini perlu diantisipasi, agar tidak membius peserta didik, menerima pewarisan karakter buruk, sebagai kader penerus perjuangan agama, bangsa dan masyarakat, maka diperlukan pembinaan. Pembinaan menjadi tugas dan tanggung jawab semua pihak, jika didasari asumsi bahwa setiap orang telah lahir dengan karakternya masing-masing, maka yang paling pertama menyentuh peserta didik, pendidikan karakter adalah orang tua, keluarga, sekolah dan Pemerintah.

Pemerintah melalui Kementerian Pendidikan Nasional, yaitu membuat peserta didik berkarakter, yang esensinya adalah membangun manusia Indonesia seutuhnya, yaitu manusia yang baik dan berkarakter. ${ }^{21}$ Pembinaan karakter, berproses melalui pembinaan orang tua, keluarga, temen sepergulan, lingkungan tempat tinggal, masyarakat, organisasi kemasyarakatan dan sekolah. Sekolah sebagai penggiat pembinaan karakter, bukan saja sekolah negeri, tetapi sumbangsih sekolah swasta, yang didirikan oleh organisasi keagamaan dan organisasi sosial, mengambil peran yang cukup besar.

Kamus Besar Bahasa Indonesia, menyebutkan, bahwa untuk mengetahui karakter seseorang yang merupakan sifat-sifat kejiwaan, watak, akhlak atau budi pekerti seseorang, melalui perilaku yang ditunjukkan. Perilaku seseorang tentu berbeda antara seseorang dengan orang lainnnya, tergantung variabel pengaitnya. Peserta didik yang hidup dalam keluarga bobrok, membut peserta didik kurang

19. Ibid, Anas Salahudin : 31 .

20 . Ibid, Anas Salahudin, halaman 30.

21 .Ibid, Anas Salahudin: 43. 
mendapat bimbingan, tidak merasakan kasih sayang, akhirnya menjadi broken home. Sifat yang demikian, mudah terjangkit virus kerusakan karakter, perilakunya bisa mengarah menjadi begal sadis, pembunuh bayaran, pemabok, begal sadis. Kenihilan karakter sebagai pengaruh lingkungan sosial, bisa terjerumus dalam pergaulan bebas, bandar, pengedar atau pengguna narkoba, pesta miras dan pergaulan bebas lainnya.

Perilaku karena kenihilan karakter, tergantung variabel pengaitnya, ibarat berbadanya garis sidik jari seseorang, maka istrumennya akan berbeda, sehingga mendiagmosenya harus teliti serta hati-hati, ibarat seorang dokter memberikan obat sesuai hasil diagnose yang dilakukannya, oleh karena itu upaya pembinaannya akan berbeda.

Secara terminologis para ahli berbada pendapat tentang pengertian karakter, Anif Punto Utomo dalam Anas Salahudin, menyatakan bahwa pembinaan karakter tidak semudah membelik tangan, tetapi bukan tidak berarti tidak bisa. Membina karakter paling baik melalui pemimpinnya. Menurutnya jika para pemimpin memiliki karakter yang kuat dan bisa diteladani, rakyat serta merta akan mengikuti. ${ }^{22}$ Pembinaan karakter tidak hanya berbasis pada variable ilmu pengetahuan hapalan, namun sangat tergantung kesadaran akan motivasi diri sebagai pemimpin, pemimpin yang memberikan keteladanan, integritas, akhlak mulia dan melalui peningkatan kompetensi, dan skill.

Pembinaan karakter mulia seseorang, banyak dipengaruhi perilaku para pemimpin dalam arti luas, seperti perilaku guru, orang tua, rekan sepergaulan, pemimpin, aparat pemerintah, lingkungan sosial, organisasi sosial, atau para tokoh juga menyandang predikat sebagai pemimpin. Pemimpin menjadi teladan, maknanya dapat diteladani, bukan saja mengajarkan atau memberitahukan contohcontoh yang hanya dalam tataran kata-kata, tetapi membuktikan apa yang dihati, sama dengan yang diucapkan dan yang dilakukannya, dalam kehidupan sehari-hari disegala aspek kehidupan.

Pada umumnya pasti ada yang karakter baik, untuk membina yang berkarakter buruk, apakah itu da'i, pemimpin kharismatik, pemimpin demokratis,

22. Opcit, Haedar Nasir ,halaman 31. 
pemimpin profesionalis, pemimpin yang fisioner, nilai-nilai moral Pancasila, untuk memperbaiki yang rusak, agar kembali kejalan yang benar. Upaya pembinaan karakter dapat dijadikan panduan adalah Alqur'an, hadits, pendapat para ahli/ pakar, untuk mencari jalan keluar mengatasi krisis karakter kader bangsa saat ini. Kesediaan mencari upaya-upaya membina krisis karakter, termasuk peserta didik merupakan pintu keluar untuk menata kehidupan keberagaman masyarakat dalam berbenagara.

\section{Upaya Pembinaan Peserta Didik.}

Peserta didik, bukan saja objek tetapi juga subjek pembinaan, jadi selain menjadi objek pembinaan, ditunut secara aktif membina diri sendiri, berdasarkan pengertian manusia adalah seorang khalifah dibumi, paling sempurna, dengan segala kesempurnaan, dibanding mahluk lain seperti hewan. Hewan hanya memiliki Insting/ kemauan tidak mampu berpikir, mempertimbangkan baik atau buruk, manusia dibekali akal untuk pikiran, menimbang baik atau tercela, untuk bersikap mental positif, terhadap perubahan.

Toto Tasmara, mengutip pendapat Napoleon Hill bahwa yang disebut dengan sikap mental positif hati membawa kebenaran, kejujuran, ikhlas, pancaindra, sesuai fungsi penciptannya, sebagai manusia. ${ }^{23}$.

Peserta didik sebagai subjek pendidikan harus lebih aktif, karena perserta didik bukan saja berkedudukan sebagai penuntut ilmu, tetapi subjek mencari ilmu. Pengertian mencari mengandung makna peserta didik lah yang aktif, pengajar bertindak sebagai mediator, motivator dan fasilitator. Bagaimana pendidikan memediasi peserta didik mampu menjadi subjek untuk mengembangkan tingkat taraf seraf, pembudayaan, pemberdayan dengan cara mengembangkan metode pembelajaran, sebagai upaya memotivasi pembinaan peserta didik.

Upaya pembinaan peserta didik sebagai mahluk sosial, beragama dan mahluk yang berakal sebagaimana dimaksudkan dalam UU No 20 Tahun 2003, melalui proses pemikiran yang sadar, sistimatis, berkesimbungan agar potensi diri seseorang berkembang secara normal, melalui jalur, jenjang dan jenis pendidikan tertentu. Tujuan pembinan peserta didik tersebut, agar mampu memotivasi diri,

23. Toto Tasmara, Kepemimpinan Berbasis Spiritual, Penerbit Gema Insani, Jakarta,Tahun2006: 8 
meningkatkan kesadaran, kompetensi serta skill, untuk menghadapi pola hidup, perubahan tata kehidupan masyarakat. Globalisasi adalah fenomena perubahan yang bergerak secara berkelanjutan, berjalan secara bersama-sama dengan proses perubahan peradaban manusia dan perubahan lingkungan sosial, yang dapat berpengaruh terhadap perubahan karakter seseorang.

Sasaran pembinaan karakter adalah peserta didik, dengan tujuan agar peserta didik sebagai generasi pelanjut, mewarisi karakter yang baik, akhlak mulia, memiliki kompetensi ilmupengetahuan, memiliki skill, agar mampu menafsirkan globalisasi secara positif dan menghindarkan pengaruh negatif, diberbagai bidang kehidupan. Pembinaan dilaksanakan dengan menjalankan fungsi-fungsi manajemen peserta didik. Manajemn Peserta Didik sebagai layanan yang memuasatkan perhatian pada pengaturan, pengawasan dan layanan siswa di kelas dan diluar kelas seperti : pengenalan, pendaftaran, layanan individual seperti pengembangan keseluruhan kemampuan, minat, kebutuhan sampai ia matang di sekolah..$^{24}$

Karakter peserta didik tentu berbeda-beda, tetapi sebagai anggota masyarakat dan warga negara Indonesia, harus sesuai dengan ideologi serta peradaban bangsa yang bermantabat. Potensi spiritual peserta didik sebagai mahluk yang beriman kepada Tuhan Yang Maha Esa, harus berkembang secara wajar agar menjadi manusia yang bertakwa, berakhlak mulia, cerdas, mandiri dan demokratis dalam kehidupan beragama, bermasyarakat dan berbangsa. Penelitian ini difokuskan pada upaya pembinaan peserta didik sebagai mahluk sosial, beragama dan mahluk yang berakal, bermoral, yang diasumsi merupakan hal sangat penting, guna mempersiapkan peserta didik menghadapi globalisasi, yang sarat dengan fenomena perubahan diberbagai aspek kehidupan masyarakat.

Upaya pembinaan peserta didik ditempuh melalui beberapa jalur, yaitu formal, non formal dan informal. Jalur formal yaitu jalur pendidikan yang terstruktur dan berjenjang mulai pendidikan dasar- negeri dan swasta, pendidikan menengah Atas Umum dan kejuruan, serta pendidikan tinggi.- negeri dan swasta. Pendidikan nonformal berupa kursus dan pelatihan, kursus pelatihan kerja dan

24. Eka Prihatin, Dr,M.Pd, Manajemen Peserta Didik, Penerbit Alfabeta, Bandung, tahun 2010: 4 
pelatihan kerja magang. Sedangkan pendidikan informal ditempuh melalui pendidikan keluarga dan lingkungan kemasyarakatan. Tetapi kita belum tahu apakah juru parkir, yang masih tergolong peserta didik itu, menempuh pendidikan di salah satu jalur pendidikan tersebut atau tidak. Diluar fokus penelitian ini, diperlukan campur tangan pemerintah melalui Organisasi Perangkat Daerah yang ada, untuk menginventarisasi, mengarahkan dan membina, sehingga pembinaan pada setiap warga negara yang memiliki hak memperolah pendidikan, dapat belajar tanpa bersekolah.

Uraian-uraian di atas, memberikan pemahaman bagaimana upaya-upya pembinaan warga negara Indonesia yang memiliki hak untuk memperoleh pembinaan, baik secara formal, nonformal dan informal, agar terbentuk karakter ideal, akhlak mulia, melalui kesadaran diri sebagai mahluk ciptaan Tuhan YMK, keteladanan para pemimpin bangsa, dan peningkatan kompetensi diri, sehingga mampu menghadapi perubahan global diberbagai aspek kehidupan.

\section{Upaya Pembinaan Karakter Peserta Didik, Menghadapi Dampak Globalisasi}

Petunjuk dasar nilai karakter manusia adalah Alqur'an, tegas memberikan petunjuk dalam Firman Allah SWT QS.Al-Qalam (68):4 "Dan sesungguhnya engkau berada di atas akblak yang agung." Nabi besar Muhammad SAW adalah manusia yang paling baik akhlaknya, paling sempurna adabnya, paling baik pergaulannya, paling indah muamalahnya, semoga shalawat dan salam senantiasa tercurahkan kepada beliau. Beliau adalah contoh bagi seluruh hamba dalam segala akhlak yang baik, segala adab yang indah dan segala muamalah yang baik. Allah 'Azza wa Jalla berfirman: "Sesunggubnya telah ada pada diri Rasulullah bagi kalian contoh yang baik bagi orang yang mengharap pertemuan dengan Allah dan hari akbir dan mengingat Allah dengan drikir yang banyak." (QS. Al-Ahzab[33]: 21)

Rasulullah Muhammad Saw, adalah manusia yang paling baik akhlaknya, manusia yang paling jujur, pantas dicontobi oleb setiap manusia. Akblak Rasulullab Saw yaitu Alqur'an, oleh karena itu pantas dicontohi, selalu membawa kebenaran. Seorang ulama berkata," Para Ulama ahli fikih dan ulama lainnya menyepakati tiga hal yang kalau benar maka hal itu akan menjadi kunci keselamatan dan masing-masing 
saling terkait yakni Islam yang murni dari bid'ah dan nafsu, jujur kepada Allah dan segala amal dan makanan yang halal". ${ }^{25}$

Dimaklumi bahwa dinegara Indonesia, berhak hidup beberapa agama sesuai UU serta kepercayaan masing-masing. Kaitannya dengan pembinaan karakter, peneliti membahas nilai-nilai yang diasumsi utama yaitu mengikuti penuntun di dalam Alqur'an dan sunnah Rasulullah Saw. dan pendapat para ahli juga dirujuk sebagai Instrumen. Istilah karakter dalam bahasa Yunani berarti mengukir corak tetap dimiliki manusia, menjadi tanda khusus yang membedakan seseorang dengan orang lainnya, pendapat lain disebut juga karakter ideal atau akhlak mulia. Karakter mengandung makna yang sangat luas, meliputi semua sifat, karakter dan watak seseorang, namun peneliti membahas sesuai kemampuan dan waktu.

Karakter menurut Napoleon Hill menggunakan istilah mental positif dan negatif dan Sudewo mengunakan istilah karakter dasar, pemimpin dan karakter pilihan. Dalam karakter dasar Sudewo menyebut salah satu ciri karakter ideal seseorang yaitu jujur. Napoleon menggunakan istilah mental positif, itulah membuat seseorang menjadi jujur. Toto Tasmara, menggunakan istilah Integrity, bermakna jujur, tentu saja tidak berbohong. Ibnu Abbas dalam Buku Lautan Ikhlas dan Kejujuran ( 2013: 125), menyebutkan empat hal yang menyebabkan manusia beruntung yakni jujur, malu, berakhlak baik dan syukur. ${ }^{26}$

Pendapat Ary Ginanjar, bahwa kekaguman pada seseorang bukan pada sosok/ ujud orangnya, melainkan pada sifat-sifat yang dimilikinya. Manakala seseorang yang dikagumi sudah tidak jujur lagi, maka kekaguman itu akan surut seketika. Karakter CEO yang sukses hasil survey The Leadership Challenge, James Mc Kouzes dan Berry Z. Postner pada tahun 1997 dan 1993, mengemukakan bahwa karakter CEO Internasional yang sukses, yaitu CEO-CEO yang memiliki sifat jujur. ${ }^{27}$

${ }^{25}$ Imam Al-Ghazali, Lautan Ikhlas dan Kejujuran, penerbit Khatulistiwa, Jakarta, tahun 2013: 125.

26. Ibid, Imam Al-Ghazali, Lautan Ikhlas dan Kejujuran, penerbit Khatulistiwa, Jakarta, tahun 2013: 125.

27. Ary Ginanjar Agustian, ESQ Power, penerbit Arga, Jakarta, 2003. 
Jujur adalah kendaraan menuju keselamatan bagi manusia. Jika manusia berada di garis kejujuran, maka kerusakan karakter terbindarkan serta keselamatanakan akan didapatkannya. Oleh karena itu dapat dimaklumi pendapat Samuel Smiles dalam Haedar Nasir ( 2013:11 ) sebagaiana dikemukakan di atas bahwa karakter dapat memberikan kedudukan terhormat dan mulia serta investasi paling berharga.

Karakter pada hakikatnya berbentuk dua dimensi, dimensi horizontal yaitu hubungan dengan sesama manusia dan vertikal yaitu hubungan dengan sang pencipta. Dalam Alqur'an maupun Sunnah Rasulullah Saw, maupun pendapat para ahli, jujur menjadi instrument terpenting untuk mengukur, seseorang berkarakter baik atau buruk. Oleh sebab itu salah satu indikator terpenting dari karakter seseorang adalah jujur yang akan menyelamatkan manusia dalam menempuh kehidupan didunia, sebelum akhirnya wajib mempertanggungjawabkan sikap dan perlakunya, secara vertikal dalam pertemuan dengan Allah SWT sang pencipta.

Dimensi horizontal, menggambarkan sikap dan berperilaku seseorang, berintegrasi dengan perilaku dari etnis lain, nilai-nilai budaya dalam lingkungan kehidupan sosial global. Globalisasi adalah proses integrasi internasional yang terjadi karena pertukaran pandangan secara dunia, produk disegala aspek kehidupan masyarakat berkembang secara menyeluruh, pemikiran berkembang diberbagai ilmu pengetahuan, seni dan aspek aspek kebudayaan lainnya terintegrasi secara luas. " Kemajuan infrastruktur transportasi dan telekomunikasi, termasuk kemunculan telegraf dan Internet, merupakan faktor utama dalam globalisasi yang semakin mendorong saling ketergantungan (interdependensi) aktivitas ekonomi dan budaya". 28

Fenomena yang terjadi sebagai pengaruh globalisasi, menggambarkan derasnya perubahan, mendatangkan pengaruh positif, mendorong motivasi, kreativitas dan inovasi seseorang dalam menjemput kemajuan Ilmu pengetahuan, tehnologi dan tehnologi informasi. Kemajuan tersebut berpengaruh pada kehidupan manusia semakin gampang, mudah dan cepat. Pengaruh negatif

${ }^{28}$. https://id.wikipedia.org/wiki/Globalisasi, diakses, 30 Desember 2019. 
membawa pengaruh negatif terhadap rusaknya karakter kader penerus bangsa tercinta yang disebut Indonesia.

Pengaruh negatif, tidak bisa diukur kerusakan karakter hanya dengan satu instrument, tergantung variabel pengaitnya, akan tetapi jika dibiarkan, maka perilaku itu akan berkembang menjadi penyakit yang kronis. Disinilah perlunya keteladanan pemimpin baik dipemerintah, pemimpin politik, penguasa sesuai jenjang kekuasaannya, kepedulian pengusaha dan fungsi juru da'wah, secara bersama-sama berupaya membina karakter bangsa termasuk peserta didik sebagai kader-kader pewaris perjuangan agama, masyarakat dan bangsa.

Manusia itu dilahirkan disertai kerakter yang suci bersih seperti kertas yang putih bersih, belum bertuliskan apa-apa, yang mencetak perilakunya buruk atau keji, yaitu lingkungan pembinaan, baik lingkungan dekat maupun jauh. Lingkungan dekat seperti pembinaan oleh orangtuanya, keluarganya, pergaulannya, sedangkan lingkungan jauh globalisasi dengan kemajuan tehnologi informasi. Namun sekarang ini sangat sulit membedakan dekat atau jauh, karena tehnologi informasi, sebagai sarana canggih media sosial, mempermudah penyebaran informasi. Penyebaran film-film fornografi, gambar-gambar forno, penipuan, judi online, dengan mudahnya menyebar melalui media sosial.

Media informasi bukan lagi sebagai barang mewah, tapi sudah menjadi sebuah kebutuhan, ironisnya anak dibawah umur pun sudah menenteng HP. Ibaratnya HP lebih penting dari pada makan, dalam keadaan berbaring pun ditemani HP, sudah menjadi kerabat terdekat. Perubahan lingkungan sosial tidak mungkin dibendung, sifatnya abadi, apakah itu membawa pengaruh positif atau negatif, karakter itulah yang harus dibina, agar memiliki karakter yang baik, berakhlak mulia, sehingga mampu menghadapi dan mengatur perubahan, bukan diatur perubahan.

Karakter seseorang berbeda dengan lainnya, dapat dikenali melalui sikap dan perilaku yang diperlihatkan. Seseorang yang menggunakan kejujuran sebagai kendaraan dan memandang perubahan sebagai rakhmat Allah SWT yang mendatang hikmah, akan menunjukkan karakter yang baik bukan zalim. Kejujuran merupkan karakter ideal dan menjadi harapan setiap orang, namun dalam perjalanan derasnya tantangan negatif globalisasi, memberi pengaruh kerusakan 
karakter. Kerusakan karakter, pengungkit utamanya, diasumsi adalah kepentingan individu, sikap emosional dalam memenuhi kepentingannya dengan berbagai cara, bahkan dengan cara yang negatif. Jika pengungkitnya negatif, muncul sikap dan perilaku negatif, seperti Korupsi, sebagai bandar narkoba, perampok, begal sadis, agen miras, sebaliknya jika seseorang itu jujur, pasti berakhlak mulia, berperilaku baik dan terpuji.

Perilaku korupsi itu sifatnya anomali yaitu terdiri dari beragam bentuk, yang tidak akan diuraikan secara rinci dalam penelitian ini. Demikian juga penyelundupan narkoba, senjata api gelap, barang mewah, juga dengan berbagai ragam cara. Namun secara logika normal, setiap orang pasti menginginkan akhlak mulia, hatta seorang perampok pun tidak pernah mendo'a anaknya untuk menjadi perampok, akan tetapi kembali kepada kemampuan diri untuk membina mental positif, sangat terbatas, sehingga tidak dapat membendung pengaruh negatif yang membentuk perilaku negatif. Perubahan sosial yang demikian pesat membangkitkan nafsu dan emosional seseorang mewujudkan harapan, dibaringi persaingan global yang sangat kompetitif, memaksa terjadinya perilaku buruk. Menciptakan akhlak mulia, memerlukan pembinaan karakter secara menyeluruh termasuk bagi peserta didik sebagai generasi pelanjut.

Generasi pelanjut akan menghadapi perubahan global secara terus menerus, pengaruh kemajuan ilmupengetahuan dan tehnologi, persaingan yang ketat, kehidupan manusia yang pariatif, menuntut motivasi, kreativitas dan inovaif. Mungkin kedepan berwiraswasta tidak perlu bersusah payah pergi ke pasar, cukup melalui media online, sekarang pun fenomena itu sudah muncul, mencari ilmu, cukup dengan duduk santai, tidak harus belajar kesekolah, dimana saja dapat belajar, didukung tehnologi informasi. Sekarang fenomena belajar secara online sudah tidak lagi asing, Universitas Terbuka, ruang guru sudah menyiapkan aplikasi belajar online, kebutuhan bahan pelajaran sudah dipaket untuk kebutuhan per semester.

Dibalik pengaruh semua perubahan itu, fenomena rusaknya karakter bangsa ini, juga menjadi masalah yang harus mendapat pembinaan. Fenomena rusaknya karakter bangsa, maraknya peredaran narkoba, justru menjadi sasaran adalah generasi muda, diluar maupun yang sedang menjadi peserta didik. Korupsi, 
masih menjadi musuh bangsa, pungli oleh aparat birokrasi karena kenilihan karakter, radikalisme dan terorisme kerena kosongnya pemahaman akan nilai-nilai agama. Pesta miras, perkelahian antar pelajar, pembunuhan, begal sadis, perampokan, tidak jarang pelakunya tergolong generasi muda, karena kenihilan karakter. Seseorang dapat dipastikan tidak ada yang menghendaki terjangkit virus negatif globalisasi, terjerumus kelembah kesengsaraan, akibat kesalahan karakternya sendiri. Mengapa keadaan itu bisa terjadi, kita bisa merujuk pendapat Koncoroningrat seorang antropolog dari Universitas Indonesia, mengatakan masyarakat Indonesia mengidap penyakit mentalitas yang meremehkan mutu, suka menerabas ( jalan pintas ), tidak percaya pada diri sendiri, tidak berdisiplin murni dan suka mengabaikan tanggung jawab. ${ }^{29}$

Globalisasi dapat dikatakan biang kerok rusaknya karakter seseorang, jika perubahan yang dicirikan dengan kemajuan tehnologi informasi, digunakan secara negatif, sehingga menjadi virus rusaknya karakter seseorang. Hal itu terjadi karena ketidak mampuan dan ketidak tahuan, serta tidak memiliki pengendalian diri yang kuat, sehingga salah kaprah memanfaatkan kemajuan tehnologi. Jika sesorang berpegang teguh pada kejujuran, memiliki pengendalian diri kuat mempertahankan karakter terpuji, akhlak mulia, pasti memiliki pendirian yang teguh untuk mempertahankan keyakinan akan kebenaran yang dipercayai, untuk menghadapi setiap perubahan yang terjadi. Karakter terpuji dan buruk, menggambarkan perbedaan karakter masing-masing individu, artinya tidak semua individu manusia sifat, tabiat, akhlaknya sama, tergantung pada kekuatan aqidahnya, sama halnya dengan keimanan seseorang, bisa kuat, lemah bahkan bisa hilang. Seseorang yang masih aqidahnya tidak mungkin akan berdusta atau berperilaku tercela.

Seseorang berperilaku tercela, melanggar perintah Allah SWT karena kenihilan karakternya, saat itu ke Imananya dicabut, dengan kata lain tidak mungkin kebaikan dicampur dengan keburukan, ibarat minuman keras, atau narkoba, tetap haram, walaupun menjadi obat. Jika perilakunya masih waras ia, pasti akan berbuat jujur dan menghindarkan diri perbuatan munkar. Artinya bahwa seseorang melakukan perbutan tercela, berdusta, ia sedang dilanda

29. Haedar Nasir, Hal : 4. 
kerusakan karakter. Dinilah pentingnya pembinaan karakter, agar tetap berkarakter baik, akhlak mulia, membudaya pada diri seseorang, sehingga bagaimanapun dahsatnya gelombang perubahan, ia akan tetap dengan sadar mengambil manfaat positif dan menghindar diri dari dampak negatif globalisasi.

Secara logika normal, tugas manusia sebagai halifah adalah mengadakan perubahan pada diri sendiri, masyarakat, kearah positif, dalam istilah Islam “ hijrah" dari kemunkaran kearah kebaikan, atau menebar kebaikan pada masyarakat, sehingga tetap dikuasi karakter baik. Maknanya manusialah yang mengandalikan perubahan, bukan sebalik perubahan memperdaya manusia. Itulah penting pembinaan, agar peserta didik sebagai generasi pelanjut, mampu menghadapi dampak negatif globalisasi. Ukuran dan cara pembinaan pun berbedabeda, sesuai kasus yang menimpa, ibarat dokter memberikan obat pada pasiennya, tentu berdasarkan hasil diagnose yang diakukan. Seorang pemabok minuman keras, beda pembinaannya dengan seorang pecandu narkoba, begitu juga begal sadis, perampok dan koruptor, walaupun sama-sama merampok hak milik rakyat.

\section{KESIMPULAN}

Globalisasi menghilangkan sekat pembatas seolah-olah membuat dunia tanpa batas dan memungkinkan pengintegrasian berbagai aspek kehidupan masyarakat, satu sama lain secara mendunia, sehingga saling mempengaruhi. Globalisasi disimbulkan dengan perkembangan ilmupengetahuan, kemajuan tehnologi informasi, kemajuan dibidang transportasi. Dampak globalisasi itu membuat persaingan menjadi semakin ketat khususnya dibidang sumber daya manusia, kehidupan seseorang menjadi semakin mudah serta cepat, sebaliknya dampak negatif akan menjadi virus perusak karakter bangsa. .

Karakter adalah hati yang membawa kejujuran, menyampaikan ucapan dengan benar dan berperilaku secara benar, tidak berdusta. Karakter seseorang itu pada hakikatnya adalah baik dan tidak ada seorangpun, hatta itu seorang perampok sekalipun pasti mendo'akan keturuannya berkarakter baik-baik. Tetapi yang membuat kerusakann karakter sehingga seseorang berbuat tidak jujur, dusta, bermental negatif, diasumsi ada konstribusi dampak negatif globalisasi. 
Harapan Indonesia ke depan adalah terciptanya peserta didik yang berkarakter ideal yaitu selalu mentaati nilai-nilai agama dan keyakinan sesuai kepercayaan masing-masing, membawa peserta didik berakhlak mulia, jujur, ikhlas. Bermoral sesuai idealogi bangsa, yang didasari saling menghargai, sopan bertindak, santun berbicara, aman, tentram, saling hormat meghormati, sehingga tercipta masyarakat dan bangsa yang adil, makmur dan sejahtera.

Untuk mewujudkan harapan itu perlu pembinaan karakter peserta didik agar mampu menghadapi dampak era globalisasi. Upaya pembinaan karakter dapat ditempuh langkah-langkah sbb :

1. Pembinaan karakter melalui pengembangan kemandirian seseorang, sebagai halifah di dunia.

2. Pembinaan karakter melalui memberikan keteladanan sebagai pemimpin diberbagai lingkungan sosial.

3. Pembinaan karakter melalui pendidikan formal, non formal dan informal.

4. Pembinaan karakter harus dilakukan secara terprogram, terstruktur, berkesinambungan seiring perubahan yang terjadi, karena sesungguhnya pembinaan itu akan memberikan manfaat.

Demikian penelitian Jurnal ini ditulis, semoga dapat menjadi salah satu acuan dalam upaya membina karakter penerus perjuangan bangsa. Amin.

\section{DAFTAR PUSTAKA}

Adig Suwandi dan Soejitno Irmin, Paradogsi Perubahan, Penerbit Seyma Media, Malang, 2004.

Anas Salahudin, Drs.M.Pd dan Irwanto Alkarienciehie, Pendidikan Karakter, Penerbit CV. Pustaka Setia Jl. Bandung, Tahun 2013: 30.

Arvan Pradiansyah, You Leader, Penerbit PT Elex Media Kokpotindo, Jakarta, tahun 2003.

Burhanuddin Salam, Filsafat Pancasila, Penerbit Bina Aksara, Jakarta, tahun 1988.

Departemen Pendidikan dan Kebudayaan, Kamus Besar Bahasa Indonesia, Penerbit Balai Pustaka, Jakarta, Tahun 1990 : 389.

Eka Prihatin, Manajemen Peserta Didik, Penerbit,Alfabeta Bandung, Tahun 2014 : 3. 
Haedar Nasir Dr, Pendidikan Karakter Berbasis Agama dan Budaya, Penerbit : Multi Presindo, Yogyakarta, Tahun 2013: 10.

Imam Al-Ghazali, Lautan Ikhlas dan Kejujuran, penerbit Khatulistiwa, Jakarta, tahun 2013: 125

Martin Worf, Globalisasi Jalan Menuju Kesejahteraan,Yayasan Obor Indonesia, Jakarta, Tahun 2004 :

Muhammad Hisyam dan Cahyo Pamungkas ( Ed ),Indonesia globalisasi dan globalisasivillage, Penerbit Yayasan Pustaka Obor Indonesia,Jakarta, tahun $2016: 6$.

Sukarti Nasihin dan Sururi, Manajemen Peserta didik,Diterbitkan oleh Alfabeta, Bandung, Tahun 2012: 203.

Tim Dosen Administrasi Pendidikan Universitas Penddikan Indonesia, Manajemen Pendidikan, Diterbitkan oleh Alfabeta, Bandung, tahun 2012 : 205.

W.J.S. Poerwadarminta, Kamus Umum Bahasa Indinesia, Penerbit Balai Pustaka, Jakarta, Tahun 1982: 137.

Wojowasito dan Tito W,Kamus Bahasa Inggris, Penerbit HASTA, Bandung, tahun $1980: 23$.

https://id.wikipedia.org/wiki/Globalisasi, diakses, 30 Desember 2019. 